\title{
PENINGKATAN HAIL BELAJAR PASSING MENGGUNAKAN KAKI BAGIAN DALAM PADA PEMBELAJARAN SEPAKBOLA DENGAN MEDIA AUDIO VISUAL
}

\author{
MOCHAMAD SLAMET PRASETYO \\ MOH. AGUNG SETIABUDI
}

\author{
Program Studi Pendidikan Jasmani, Kesehatan, dan Rekreasi \\ Fakultas Olahraga Kesehatan \\ Universitas PGRI Banyuwangi \\ Email: prasetyochelsea197@yahoo.com, agungsetiabudi.budi@gmail.com
}

\begin{abstract}
ABSTRAK
Penelitian ini bertujuan untuk mengetahui peningkatan hasil belajar passing menggunakan kaki bagian dalam pada pembelajaran sepakbola dengan media audio visual pada siswa kelas XI TKR di SMK Taruna Mandiri Srono. Jenis penelitian ini adalah penelitian tindakan kelas (PTK), dilaksanakan dalam dua siklus. Tiap siklus terdiri dari rencana tindakan, pelaksanaan, observasi/ evaluasi, refleksi. Subyek penelitian adalah siswa kelas XI SMK Taruna Mandiri Srono yang berjumlah 30 siswa putra. Metode analisis data menggunakan analisis statistik deskriptif.

Hasil penelitian menunjukkan hasil belajar pada siklus I, siswa dalam kategori sangat baik sebanyak 0 orang $(0 \%)$, siswa dalam kategori baik sebanyak 16 orang $(53,3 \%)$, siswa dalam kategori cukup baik sebanyak 14 orang $(46,7 \%)$, siswa dalam kategori kurang baik sebanyak 0 orang $(0 \%)$ dan siswa dalam kategori sangat kurang baik tidak ada. Siswa yang tuntas sebanyak $16(53,3 \%)$ orang dan siswa yang tidak tuntas sebanyak 14 orang $(46,7 \%)$ orang. Sehingga persentase ketuntasan hasil belajar secara klasikal adalah 75,8 dan berada pada kategori baik. Hasil belajar pada siklus II, siswa dalam kategori sangat baik sebanyak 3 orang (10\%), siswa dalam kategori baik sebanyak 21 orang $(70 \%)$, siswa dalam kategori cukup baik sebanyak 6 orang $(20,0 \%)$, siswa dalam kategori kurang baik dan siswa dalam kategori sangat kurang baik tidak ada. Siswa yang tuntas sebanyak 24 orang $(80,0 \%)$ dan siswa yang tidak tuntas sebanyak 6 orang (20,0\%). Sehingga Persentase ketuntasan hasil belajar secara klasikal adalah 78,9 dan berada pada kategori baik. Terjadi peningkatan 3,1 dari siklus I ke siklus II.
\end{abstract}

Kata kunci: Media Audio Visual, Hasil Belajar, Passing Menggunakan kaki bagian dalam

\section{PENDAHULUAN}

Pendidikan

Jasmani,

Olahraga dan Kesehatan merupakan bagian integral dari pendidikan secara keseluruhan, bertujuan untuk mengembangkan aspek kebugaran jasmani, keterampilan gerak, keterampilan sosial, penalaran, stabilitas emosional, tindakan moral, aspek pola hidup sehat dan pengenalan lingkungan bersih melalui aktivitas jasmani, olahraga 
dan kesehatan terpilih yang direncanakan secara sistematis dalam rangka mencapai tujuan pendidikan nasional (Depdiknas, 2006: 163).

Perlu disadari bahwa keberhasilan dari suatu proses pembelajaran penjasorkes ditentukan oleh banyak faktor seperti guru, model pembelajaran, sarana dan prasarana, dan situasi dalam proses belajar mengajar. Misalnya pada pembelajaran sepakbola menggunakan kaki bagian dalam yang tentunya harus menjelaskan dan memberikan contoh gerakan yang baik dan benar yang pasti akan memerlukan banyak waktu jika guru hanya menggunakan metode ceramah tanpa ada alat bantu apapun. Padahal jika menggunakan media audio visual akan lebih menghemat waktu yang disajikan oleh guru (Soepartono dalam Sayuti, 2015:72).

Peneliti memeberikan solusi untuk mengatasi hal-hal tersebut adalah dengan menggunakan media audio visual sebagai alat proses pembelajaran, dengan menggunakan media sebagai alat pembelajaran dapat memberikan gambaran informasi yang sangat bermanfaat bagi guru maupun siswa. Media audio visual adalah jenis media yang digunakan dalam kegiatan pembelajaran dengan melibatkan pendengaran dan penglihatan sekaligus dalam satu proses atau kegiatan. Pesan dan informasi yang dapat disalurkan melalui media ini dapat berupa pesan verbal dan nonverbal yang mengandalkan baik penglihatan maupun pendengaran. Beberapa contoh media audio visual adalah film, video, program TV dan lain-lain (Azhar Asyhad, 2011:45).

Masalah yang ditemui penenulis saat melaksanakan observasi awal di SMK Taruna
Mandiri Srono adalah kurangnya minat siswa dalam mengikuti proses pembelajaran sepakbola khususnya pada teknik passing menggunakan kaki bagian dalam, siswa cenderung diam ketika guru menggunakan metode ceramah setelah itu dilanjutkan praktik di lapangan. Padahal sarana dan prasarana yang ada di SMK Taruna Mandiri Srono yang menunjang untuk pembelajaran menngunakan media audio visual.

Berdasarkan uraian tersebut penulis tertarik melakukan penelitian dengan judul" Peningkatan Hasil Belajar Passing Menggunakan Kaki Bagian Dalam Pada Pembelajaran Sepakbola Dengan Media Audio Visual".

\section{Hasil Belajar}

Hasil belajar adalah perubahan perilaku peserta didik yang dicapai setelah melaksanakan proses belajar dimana perubahan perilaku tersebut meliputi aspek kognitif, afektif, dan psikomotorik. Perubahan perilaku tersebut disebabkan karena pencapaian penguasaan atas sejumlah bahan yang diberikan dalam proses belajar mengajar.

\section{Sepakbola}

Sepakbola adalah suatu permainan yang dilakukan dengan menendang bola kian-kemari untuk diperebutkan pra pemain-pemain, yang mempunyai tujuan untuk memasukan bola ke gawang lawan juga mempertahankan gawang sendiri agar tidak kemasukan bola. Dalam permainan ini, setiap pemain diperbolehkan menggunakan seluruh anggota badan kecuali tangan dan lengan. Hanya penjaga gawang yang diperbolehkan memainkan bola 
dengan kaki dan tangan di daerah gawang (Muhajir, 2004:22).

\section{Media Pembelajaran Audio Visual}

Media pembelajaran adalah setiap orang, bahan, alat, atau peristiwa yang dapat menciptakan kondisi yang memungkinkan belajar untuk menerima pengetahuan, keterampilan dan sikap. Dengan pengetian itu, maka guru atau dosen, buku ajar, serta lingkungan adalah media (Sri Anita dalam Purwono, 2014:129).

media audio visual adalah jenis media yang digunakan dalam kegiatan pembelajaran dengan melibatkan pendengaran dan penglihatan sekaligus dalam satu proses atau kegiatan. Pesan dan informasi yang dapat disalurkan melalui media ini dapat berupa pesan verbal dan nonverbal yang mengandalkan baik penglihatan maupun pendengaran. Beberapa contoh media audio visual adalah film, video, program TV dan lainlain (Azhar Asyhad (2011:45).

Menurut Syaiful Bahri dan Aswan Zain dalam Purwono (2014:131) membagi audio visual menjadi dua yaitu:

1. Audio Visual diam, yaitu media yang menampilkan suaara dan gambar seperti bingkai suara (sound slide)

2. Audio Visual gerak, yaitu media yang dapat menampilkan unsur suara dan gambar bergerak seperti film dan video.

Menurut Atoel dalam

Purwono (2014:131) menyatakan bahawa, media audio visual memilki beberapa kelebihan atau kegunaan antara lain:

1. Memperjelas penyajian pesan agar tidak terlalu bersifat verbalistis (dalam bentuk katakata, tertulis atau lisan).

2. Mengatasi keterbatasan ruang, waktu dan daya indra, seperti: objek yang terlalu besar digantikan dengan realitas, gambar, film bingkai, film dan model.

3. Media audio visual bisa berperan dalam pembelajaran tutorial.

\section{METODE}

Penelitian ini merupakan penelitian tindakan kelas (PTK) dilaksanakan dalam dua siklus. Tiap siklus terdiri dari rencana tindakan, pelaksanaan, observasi/ evaluasi, refleksi. dengan menggunakan metode analisis stastik deskriptif.

Penentuan daerah penelitian dalam penelitian ini menggunakan purposive area yaitu SMK Taruna Mandiri Srono. Populasi dalam penelitian ini adalah siswa kelas XI TKR SMK Taruna Mandiri Srono sebanyak 30 siswa dengan pengambilan sample menggunakan populasi riset.

Teknik pengumpulan data dalam penelitian ini, yaitu dimulai dengan observasi awal dengan tujuan untuk mengetahui kemampuan awal siswa dalam pembelajaran teknik passing menggunakan kaki bagian dalam pada sepakbola dan dilanjutkan ke siklus I untuk mengukur kemampuan dan membandingkan peningkatan hasil belajar passing menggunakan kaki bagian dalam pada sepakbola setelah diberikan rencana, pelaksanaan, tindakan, observasi, dan refleksi hasil belajar passing menggunakan kaki bagian dalam pada sepakbola. Siklus II dilaksanakan untuk memperbaiki dan meningkatkan hasil belajar passing menggunakan kaki bagian dalam 
pada sepakbola setelah adanya dilakukan selama 1 bulan.

refleksi pada siklus I. Penelitian

\section{HASIL DAN PEMBAHASAN}

\section{Hasil Penelitian}

Hasil penelitian pada observasi awal yang dilakaukan penulis didapatkan data dari hasil penelitian sebagai berikut :

\begin{tabular}{|c|c|c|c|c|}
\hline $\begin{array}{c}\text { Interval } \\
\text { Nilai } \\
\end{array}$ & Kategori & $\begin{array}{c}\text { Jumlah } \\
\text { siswa }\end{array}$ & Presentase & Ketuntasan \\
\hline $85-100$ & Sangat baik & 0 & $0 \%$ & \multirow{2}{*}{$\begin{array}{l}9 \text { orang tuntas } \\
\qquad(30 \%)\end{array}$} \\
\hline $75-84$ & Baik & 9 & $30 \%$ & \\
\hline $45-74$ & Cukup baik & 21 & $70 \%$ & \multirow{3}{*}{$\begin{array}{c}21 \text { orang tidak } \\
\text { tuntas }(70 \%)\end{array}$} \\
\hline $25-44$ & Kurang baik & 0 & $0 \%$ & \\
\hline $0-24$ & Sangat kurang & 0 & $0 \%$ & \\
\hline \multicolumn{2}{|c|}{ Jumlah } & 30 & $100 \%$ & $\begin{array}{c}30 \text { orang } \\
(100 \%)\end{array}$ \\
\hline
\end{tabular}

Berdasarkan tabel 1. maka dapat dijelaskan bahwa sebanyak 0 orang $(0 \%)$ siswa yang berada pada kategori sangat baik, sebanyak 9 orang $(30 \%)$ berada pada kategori baik, sebanyak 21 orang $(70 \%)$ berada pada kategori cukup baik, sebanyak 0 orang $(0 \%)$ berada pada kategori kurang baik, dan sebanyak 0 orang ( $0 \%$ ) berada pada kategori sangat kurang baik. Jadi jumlah siswa tuntas adalah 9 orang $(30 \%)$ dan jumlah siswa yang tidak tuntas adalah 21 orang (70\%).

Berdasarkan analisis data hasil belajar pada observasi awal, maka nilai rata-rata hasil belajar passing menggunakan kaki bagian dalam pada pembelajaraan sepakbola secara klasikal yaitu sebagai berikut :

$$
\bar{X}=\frac{\sum X}{N}
$$

(Sumber: Nurhasan, 2001:61)
Diketahui:

$\sum X \quad: \quad 2024$ (jumlah seluruh nilai siswa)

$N \quad: \quad 30$ (jumlah siswa)

$\bar{X} \quad: 67,5$

Sedangkan persentase ketuntasan hasil belajar siswa secara klasikal yaitu sebagai berikut:

$$
\begin{aligned}
K \mathrm{~B} & =\frac{\text { Jumlah Siswa yang Tuntas }}{\text { Jumlah Siswa Keseluruhan }} \times 100 \% \\
& =\frac{9}{30} \times 100 \% \\
& =30 \%
\end{aligned}
$$

Hasil penelitian pada siklus I didapatkan hasil penelitian sebagai berikut : 


\section{Tabel 2. Hasil Analisis Data Hasil Belajar Teknik Dasar Passing Menggunakan Kaki Bagian Dalam pada Sepakbola Siklus I}

\begin{tabular}{ccccc}
\hline Interval Nilai & Kategori & Jumlah siswa & Presentase & Ketuntasan \\
\hline $\mathbf{8 5}-\mathbf{1 0 0}$ & Sangat baik & 0 & $0 \%$ & 16 orang tuntas \\
$\mathbf{7 5}-\mathbf{8 4}$ & Baik & 16 & $53,3 \%$ & $(53,3 \%)$ \\
$\mathbf{4 5}-\mathbf{7 4}$ & Cukup baik & 14 & $46,7 \%$ & \\
$\mathbf{2 5}-\mathbf{4 4}$ & Kurang baik & 0 & $0 \%$ & 14 orang tidak \\
$\mathbf{0 - 2 4}$ & Sangat kurang & 0 & $0 \%$ & tuntas (46,7 \%) \\
\hline \multicolumn{2}{c}{ Jumlah } & 30 & $100 \%$ & 30 orang (100\%) \\
\hline
\end{tabular}

Berdasarkan tabel 2. maka dapat dijelaskan bahwa sebanyak 0 orang $(0 \%)$ siswa yang berada pada kategori sangat baik, sebanyak 16 orang $(53,3 \%)$ berada pada kategori baik, sebanyak 14 orang $(46,7 \%)$ berada pada kategori cukup baik, sebanyak 0 orang $(0 \%)$ berada pada kategori kurang baik, dan sebanyak 0 orang ( $0 \%)$ berada pada kategori sangat kurang baik. Jadi jumlah siswa tuntas adalah 16 orang $(53,3 \%)$ dan jumlah siswa yang tidak tuntas adalah 14 orang $(46,7 \%)$.

Berdasarkan analisis data hasil belajar pada observasi awal, maka nilai rata-rata hasil belajar passing menggunakan kaki bagian dalam pada pembelajaraan sepakbola secara klasikal yaitu sebagai berikut :

$$
\bar{X}=\frac{\sum X}{N}
$$

(Sumber: Nurhasan, 2001:61)
Diketahui:

$\sum X \quad$ : 2273,5 (jumlah seluruh nilai siswa)

$N \quad: \quad 30$ (jumlah siswa)

$\bar{X} \quad: \quad 75,8$

Sedangkan persentase ketuntasan hasil belajar siswa secara klasikal yaitu sebagai berikut:

$$
\begin{aligned}
K \mathrm{~B} & =\frac{\text { Jumlah Siswa yang Tuntas }}{\text { Jumlah Siswa Keseluruhan }} \times 100 \% \\
& =\frac{16}{30} \times 100 \% \\
& =53,3 \%
\end{aligned}
$$

Hasil penelitian pada siklus II didapatkan hasil penelitian sebagai berikut :

Tabel 3. Hasil Analisis Data Hasil Belajar Teknik Dasar Passing Menggunakan Kaki Bagian Dalam pada Sepakbola Siklus II

\begin{tabular}{ccccc}
\hline Interval Nilai & Kategori & Jumlah siswa & Presentase & Ketuntasan \\
\hline $\mathbf{8 5}-\mathbf{1 0 0}$ & Sangat baik & 3 & $10 \%$ & 24 orang tuntas \\
$\mathbf{7 5 - 8 4}$ & Baik & 21 & $70 \%$ & $(80 \%)$ \\
$\mathbf{4 5}-\mathbf{7 4}$ & Cukup baik & 6 & $20 \%$ & 6 orang tidak \\
$\mathbf{2 5}-\mathbf{4 4}$ & Kurang baik & 0 & $0 \%$ & tuntas (20\%) \\
$\mathbf{0 - 2 4}$ & Sangat kurang & 0 & $0 \%$ & 30 orang (100\%) \\
\hline
\end{tabular}


Berdasarkan tabel 3. maka dapat dijelaskan bahwa sebanyak 3 orang $(10 \%)$ siswa yang berada pada kategori sangat baik, sebanyak 21 orang $(70 \%)$ berada pada kategori baik, sebanyak 6 orang (20\%) berada pada kategori cukup baik, sebanyak 0 orang $(0 \%)$ berada pada kategori kurang baik, dan sebanyak 0 orang ( $0 \%$ ) berada pada kategori sangat kurang baik. Jadi jumlah siswa tuntas adalah 24 orang $(80 \%)$ dan jumlah siswa yang tidak tuntas adalah 6 orang $(20 \%)$.

Berdasarkan analisis data hasil belajar pada observasi awal, maka nilai rata-rata hasil belajar passing menggunakan kaki bagian dalam pada pembelajaraan sepakbola secara klasikal yaitu sebagai berikut :

$$
\bar{X}=\frac{\sum X}{N}
$$

(Sumber: Nurhasan, 2001:61)

Diketahui:

$\sum X \quad$ : 2367 (jumlah seluruh nilai siswa)

$N \quad: \quad 30$ (jumlah siswa)

$\bar{X} \quad: \quad 78,9$

Sedangkan persentase ketuntasan hasil belajar siswa secara klasikal yaitu sebagai berikut:

$$
\begin{aligned}
K \mathrm{~B} & =\frac{\text { Jumlah Siswa } y \text { ang Tuntas }}{\text { Jumlah Siswa Keseluruhan }} \times 100 \% \\
& =\frac{24}{30} \times 100 \% \\
& =80 \%
\end{aligned}
$$

Hasil analisis data hasil belajar teknik dasar passing menggunakan kaki bagian dalam pada sepakbola pada siswa kelas XI TKR SMK Taruna Mandiri Srono tahun pelajaran 2016/2017 dapat diketahui bahwa, pada observasi awal terdapat 9 orang siswa yang tuntas (30\%), setelah diberikan tindakan pada siklus I, siswa yang tuntas menjadi 16 orang $(53,3 \%)$ dengan peningkatan 7 orang $(23,3 \%)$. Kemudian dilanjutkan dengan pemberian tindakan pada siklus II, siswa yang tuntas yaitu 24 orang $\mathrm{k}(80,0 \%)$ dengan peningkatan 8 orang $(26,7 \%)$ dari siklus I, dan peningkatan dari observasi awal ke siklus II yaitu 15 orang (50\%).

\section{Pembahasan}

Data hasil belajar teknik dasar menggunakan kaki bagian dalam pada sepakbola pada observasi awal menunjukkan bahwa siswa yang tuntas 9 orang (30\%) dan yang tidak tuntas 21 orang $(70 \%)$. Ratarata hasil belajar siswa secara klasikal yaitu 67,5 angka ini termasuk dalam kategori cukup dilihat dari pedoman Kriteria Ketuntasan Minimal (KKM) kelas XI TKR SMK Taruna Mandiri Srono untuk mata pelajaran penjasorkes tahun pelajaran 2016/2017. Dari hasil analisis hasil belajar di atas, permasalahan yang dihadapi siswa yaitu (a) pada aspek kognitif, siswa masih banyak yang kurang memahami teori dari materi passing menggunakan kaki bagian dalam pada sepakbola secara mendalam, (b) pada aspek afektif, masih banyak siswa yang kurang berani dalam melakukan gerakan ataupun membantu teman yang kurang mampu, (c) pada aspek psikomotor, siswa masih keliru dalam melakukan gerakan teknik dasar passing menggunakan kaki bagian dalam pada sepakbola yaitu pada sikap awal, pelaksanaan dan sikap akhir. 
Setelah diberi tindakan pada siklus I, data hasil belajar teknik dasar passing menggunakan kaki bagian dalam pada sepakbola pada siklus I menunjukkan bahwa terdapat 16 orang siswa tuntas $(53,3 \%)$ dan 14 orang siswa yang tidak tuntas $(46,7 \%)$. Berdasarkan data tersebut, maka diketahui bahwa perolehan rata-rata hasil belajar siswa secara klasikal yaitu 75,8. Meski sudah mengalami peningkatan dari observasi awal ke siklus I sebesar $23,3 \%$.

Dari hasil analisis hasil belajar, permasalahan yang dihadapi siswa yaitu (a) pada aspek kognitif, siswa masih banyak yang kurang memahami teori dari materi teknik dasar passing menggunakan kaki bagian dalam pada sepakbola secara mendalam, (b) pada aspek afektif, masih banyak siswa yang kurang berani dalam melakukan gerakan ataupun membantu teman yang kurang mampu, (c) pada aspek psikomotor, siswa masih keliru dalam melakukan gerakan teknik dasar passing menggunakan kaki bagian dalam pada sepakbola diantaranya sikap awal, posisi kaki pada saat pelaksanaan masih banyak yang salah, posisi lengan masih belum lurus pada saat melakukan passing dan pandangan mereka belum ke arah sasaran.

Setelah diberi tindakan pada siklus II, data hasil belajar teknik dasar passing menggunakan kaki bagian dalam pada sepakbola pada siklus II menunjukkan terdapat 24 orang siswa yang tuntas $(80,0 \%)$ dan 6 orang siswa yang cukup baik $(20,0 \%)$. Rata-rata hasil belajar siswa secara klasikal yaitu 78,9 angka ini termasuk dalam kategori baik dilihat dari pedoman Kriteria Ketuntasan Minimal (KKM) kelas XI TKR SMK
Taruna Mandiri Srono untuk mata pelajaran penjasorkes tahun pelajaran 2016/2017. Dari siklus I ke siklus II, hasil belajar siswa mengalami peningkatan sebesar 8 orang $(26,7 \%)$, dan peningkatan dari observasi awal ke siklus II yaitu berjumlah 15 orang (50\%). Karena hasil belajar siswa sudah memenuhi kriteria ketuntasan minimal, maka penelitian dihentikan dan keberhasilan pembelajaran terpenuhi melalui penerapan model pembelajaran audio visual.

\section{KESIMPULAN}

Berdasarkan hasil analisis data dan pembahasan, dapat dijelaskann sebagai berikut:

Hasil belajar passing menggunakan kaki bagian dalam pada pembelajaran sepakbola siswa kelas XI TKR SMK Taruna Mandiri Srono Tahun Pelajaran 2016/2017. Hal ini bisa di lihat dari hasil belajar pada siklus 1, siswa dalam kategori sangat baik sebanyak 0 orang $(0 \%)$, siswa dalam kategori baik sebanyak 16 orang (53,3\%), siswa dalam kategori cukup baik sebanyak 14 orang $(46,7 \%)$, siswa dalam kategori kurang baik sebanyak 0 orang $(0 \%)$ dan siswa dalam kategori sangat kurang baik tidak ada. Siswa yang tuntas sebanyak $16(53,3 \%)$ orang dan siswa yang tidak tuntas sebanyak 14 orang $(46,7 \%)$ orang. Sehingga persentase ketuntasan hasil belajar secara klasikal adalah 75,8 dan berada pada kategori baik. Hasil belajar pada siklus 2, siswa dalam kategori sangat baik sebanyak 3 orang $(10 \%)$, siswa dalam kategori baik sebanyak 21 orang (70\%), siswa dalam kategori cukup baik sebanyak 6 orang $(20,0 \%)$, siswa dalam kategori kurang baik dan siswa dalam kategori sangat kurang baik 
tidak ada. Siswa yang tuntas sebanyak 24 orang $(80,0 \%)$ dan siswa yang tidak tuntas sebanyak 6 orang $(20,0 \%)$. Sehingga Persentase ketuntasan hasil belajar secara klasikal adalah 78,9 dan berada pada kategori baik. Terjadi peningkatan 3,1 dari siklus 1 ke siklus 2 .

\section{DAFTAR PUSTAKA}

Arsyad, A. 2016. Media Pembelajaran. Jakarta: PT. Raja Grafindo Persada.

Depdiknas. 2006. Kurikulum 2006 Standar Kompetensi Mata Pelajaran Pendidikan Jasmani. Jakarta..

Muhajir. 2016. Pendidikan Jasmani, Olahraga, dan Kesehatan. Kementrian Pendidikan dan Kebudayaan Republik Indonesia.

Nurhasan. 2001. Tes dan

Pengukuran Dalam

Pendidikan Jasmani. Jakarta: Direktorat Jenderal Olahraga, Depdiknas.

Purwono, J. 2014. Penggunaan Audio Visual Pada Mata Pelajaran Ilmu Pengetahuan Alam. Pacitan.

Sayuti, P. 2015. Penerapan Audio Visual Terhadap Hasil Belajar Passing Kaki Bagian Dalam Pada Permainan Sepakbola. Surabaya 